\section{(A) Check for updates}

Cite this: Dalton Trans., 2017, 46 10399
Received 14th June 2017,

Accepted 13th July 2017

DOI: 10.1039/c7dt02162c

rsc.li/dalton

\title{
Reactivity of $\mathrm{N}$-heterocyclic carbene-pyridine palladacyclopentadiene complexes toward halogen addition. The unpredictable course of the reaction $\dagger$
}

\author{
Fabiano Visentin, ${ }^{a}$ Claudio Santo, ${ }^{a}$ Thomas Scattolin, ${ }^{a}$ Nicola Demitri ${ }^{\mathrm{b}}$ and \\ Luciano Canovese (D)*a
}

\begin{abstract}
As an extension of a previously published work we have reacted some palladacyclopentadiene complexes stabilized by bidentate $\mathrm{N}$-heterocyclic carbene-pyridine or monodentate $\mathrm{N}$-heterocyclic carbene-pyridine and isocyanide ligands with the halogens $\mathrm{I}_{2}$ and $\mathrm{Br}_{2}$. All the bidentate and monodentate complexes react with halogens to give at first the expected $\sigma$-coordinated butadienyl fragment. However, two of the less hindered NHC carbene-pyridine bidentate butadienyl iodo derivatives undergo a further rearrangement and novel $\mathrm{Pd}(॥)$ complexes characterized by a ten term coordinative ring were isolated and characterized. In the most favorable case we were able to carry out the kinetics of rearrangement and measure its reaction rate. Moreover, we have surmised a plausible mechanism on the basis of a dedicated computational approach and in one case the surprising structure characterized by the ten term coordinative ring was resolved by $\mathrm{X}$-ray diffraction.
\end{abstract}

\section{Introduction}

The organometallic palladacyclopentadiene fragment $\mathrm{Pd}(\mathrm{C}-$ COOR $)_{4}$ is an important synthetic intermediate that is involved in $\operatorname{Pd}(0)$ catalyzed $[2+2+2]$ alkyne cyclotrimerization and alkyne-alkene, alkyne-diene or alkyne-allene cocyclotrimerization. ${ }^{1}$ Its synthesis is based on a well-established protocol ${ }^{1 a-e}$ and the mechanism of its formation was deeply investigated and is well known. ${ }^{2}$

However, the palladacyclopentadiene fragments are still worthy of investigation owing to their peculiar reactivity. In particular, these derivatives easily undergo oxidative attack by halogens, interhalogens or organic halides usually yielding a $\mathrm{Z}-\mathrm{Z}$ substituted butadiene fragment $\sigma$-coordinated to the metal as a consequence of oxidative addition and reductive elimination. ${ }^{3}$ Thereafter, the butadiene fragment can be removed from the complex by successive reactions with organotin reagents $^{2 a}$ or molecular halogens in excess. ${ }^{3 a, 4}$

The oxidative addition and reductive elimination processes involve, in these cases, a $\mathrm{Pd}(\mathrm{II})-\mathrm{Pd}(\mathrm{IV})-\mathrm{Pd}(\mathrm{II})$ conversion, ${ }^{5}$ yielding conjugated dienes which are bioactive compounds con-

\footnotetext{
${ }^{a}$ Dipartimento di Scienze Molecolari e Nanosistemi, Università Ca' Foscari, Venice, Italy.E-mail: cano@unive.it

${ }^{b}$ Elettra - Sincrotrone Trieste, S.S. $14 \mathrm{Km} 163.5$ in Area Science Park, 34149 Basovizza, Trieste, Italy

$\dagger$ Electronic supplementary information (ESI) available. CCDC 1554851 and 1554852. For ESI and crystallographic data in CIF or other electronic format see DOI: $10.1039 / \mathrm{c} 7 \mathrm{dt} 02162 \mathrm{c}$
}

tained in several natural products. Since such a process was by far less studied than the $\operatorname{Pd}(0)-\operatorname{Pd}(\mathrm{II})-\operatorname{Pd}(0)$ sequence $^{6}$ we think that it is still worthy of investigation. In particular, we have published some years ago ${ }^{1 g, h}$ and recently ${ }^{3 a-d, 4}$ some studies involving the reactivity of palladacyclopentadiene complexes stabilized by different spectator ligands. The information we have gathered can be summarized as follows: (i) the nature of the spectator ligands markedly influences the reactivity of their palladacyclopentadiene derivatives, and (ii) sometimes the spectators may change their obvious role and become actor ligands. ${ }^{3 b}$

In this context we were prompted to study the reactivity toward the oxidative addition of molecular halogens to some palladacyclopentadiene complexes characterized by the presence of heteroditopic carbene ligands that we have recently synthesized. ${ }^{7}$

The studied palladacyclopentadiene complexes and the related oxidative addition/reductive elimination products carried out with $\mathrm{Br}_{2}$ or $\mathrm{I}_{2}$ are summarized in the following Scheme 1 .

\section{Results and discussion}

Synthesis of the $\sigma$-butadienyl pyridyl-carbene bromo-complexes Addition under an inert atmosphere of a stoichiometric amount of molecular bromine to type 1 complexes bearing carbene-pyridine acting as a bidentate ligand in anhydrous $\mathrm{CH}_{2} \mathrm{Cl}_{2}$ induces the formation in few minutes of the deriva- 

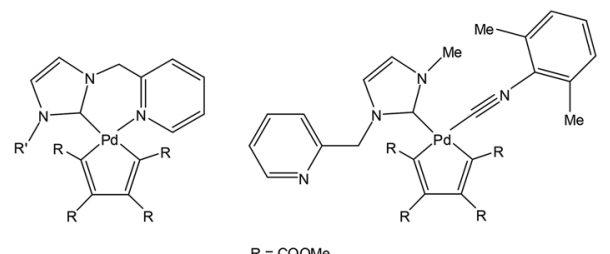

$1 d$

$R^{\prime}=$ Methyl $($ Me); 1 a

$R^{\prime}=$ Mesityl (Mes); 1 b

$R^{\prime}=$ Di-isopropyiphenyl (Dipp); $1 c$
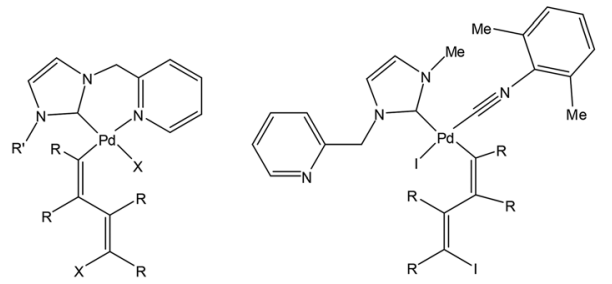

$R^{\prime}=$ Methyl $(M e) ; X=B r ; 2 a ; X=1 ; 3 a$

$R^{\prime}=$ Mesityl (Mes); $X=B r, 2 \mathbf{b} ; X=1 ; 3 \mathbf{b}$

$R^{\prime}=$ Di-isopropylphenyl $(D i p p) ; X=B r ; 2 c ; X=1 ; 3 c$

Scheme 1 Starting palladacyclopentadiene complexes (1) and $\sigma$-butadienyl derivatives $(2,3)$.

tives 2 , as can be noticed from the discoloration of the initial mixture. Eventually, the bidentate derivatives 2 can be easily precipitated off by the addition of diethylether to the pre-concentrated final solution and characterized by NMR (see selected ${ }^{1} \mathrm{H}$ and ${ }^{13} \mathrm{C}$ NMR spectra in Fig. S1 and S2 in the ESI ${ }^{\dagger}$ and the Experimental section). As reported elsewhere, ${ }^{3 a, 5 c}$ the overall reaction can be interpreted on the basis of the attack of molecular halogen forming a $\operatorname{Pd}(\mathrm{Iv})$ octahedral intermediate collapsing into the final $\sigma$-butadienyl derivative (see Scheme 2). Notably, only the isomer bearing the $\sigma$-butadienyl fragment cis to the carbene of the bidentate ligand with the carbomethoxy substituents assuming the $\mathrm{Z}-\mathrm{Z}$ configuration was formed. All the signals belonging to the spectator ligands are detected, in particular the peak at $c a .9 .15 \mathrm{ppm}$ of the $\mathrm{H}^{6}$ of the pyridine ring which is diagnostic in assessing the absolute configuration of the geometric isomer. As a matter of fact such a low field frequency is typical of the pyridine $\mathrm{H}^{6}$ on the same side of the bromide coordinated to palladium, thereby indicating their mutual cis position (ref. 4 and references therein). As a further confirmation of the isomeric nature of the type 2 and 3 complexes we have recorded the NOESY NMR

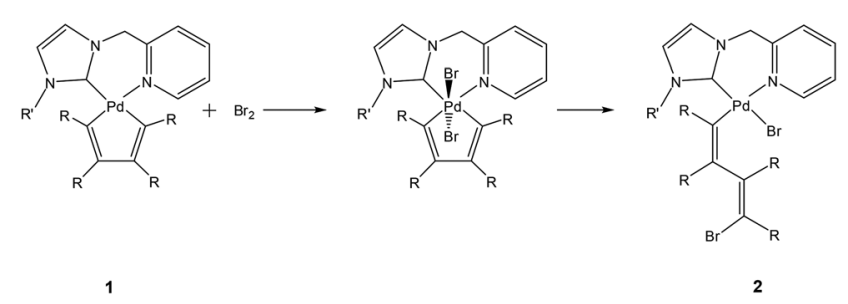

Scheme 2 Proposed mechanism for the attack of bromine to palladacyclobutadiene complexes. spectrum of complex $\mathbf{2} \mathbf{b}$. The observed cross-peaks between the $\mathrm{COOCH}_{3}$ protons of the butadienyl fragment with the $o$-methyl protons of the mesityl substituent of the imidazole ring witness their mutual cis position (see Fig. S3a, ESI†).

Moreover, the not-planar conformation of the chelate $\mathrm{C}-\mathrm{N}$ heteroditopic ligand coupled with the perpendicular location of the butadienyl fragment with respect to the main coordination plane induces the formation of a couple of endo and exo atropoisomers with the related enantiomers (Fig S3b; ESI $\dagger$ ). As can be seen in Fig S3c (ESI $\dagger$ and the Experimental section) the ${ }^{1} \mathrm{H}$ NMR spectrum of the less hindered complex 2a recorded at RT displays the concomitant presence in solution of two species at different concentrations (isomeric ratio $1: 6)$. We assume that the most abundant atropoisomer is the less crowded species exo in which the carbenic methyl substituent and the perpendicular butadienyl fragment lie at the opposite side of the main coordination plane. This conclusion is also confirmed by the DFT calculations which indicate the atropoisomer exo as the more stable species (Fig S3b; ESI $\dagger$ ). At variance with complex $2 \mathrm{a}$, in the ${ }^{1} \mathrm{H}$ NMR spectra of the more hindered complexes $\mathbf{2 b}$ and $\mathbf{2 c}$ only one species (presumably the exo isomer) is detectable at RT. Finally, the methyl protons and carbons of the ester resonate at four different frequencies with respect to those of the starting palladacyclobutadienyl complexes in both ${ }^{1} \mathrm{H}$ and ${ }^{13} \mathrm{C}$ NMR spectra whereas the terminal butadienyl carbon bound to bromide is detected at $c a$. $120 \mathrm{ppm}$.

\section{Synthesis of the $\sigma$-butadienyl pyridyl-carbene iodo-complexes}

Despite its reduced oxidative capability molecular iodine also reacts with the palladacyclobutadiene complexes. The initial violet solution fades away in about 10 minutes to give the $\sigma$ butadienyl derivatives 3 which can be separated from the reaction mixture analogously to type 2 complexes. As can be seen in Fig. S4 and S5 (ESI $\dagger$ and the Experimental section) the NMR spectra of the complexes 3 are comparable to those of type 2 species. In particular, the low field resonance of pyridine $\mathrm{H}^{6}$ at ca. $9.3 \mathrm{ppm}$ confirms that the opening of the cyclic butadiene occurs trans to the carbene carbon also in this case (ref. 4 and references therein). The four different frequencies of the ester methyl protons and carbons in the ${ }^{1} \mathrm{H}$ and ${ }^{13} \mathrm{C}$ NMR spectra, the diastereotopicity of the methylenic $-\mathrm{CH}_{2}-$ protons, the carbene carbon bound to palladium at 165-170 ppm and the terminal butadienyl carbons bound to iodide at $c a .100 \mathrm{ppm}$ suggest a distribution of the substituents at palladium analogous to that of complexes 2 . Also in this case the $\mathrm{RT}{ }^{1} \mathrm{H}$ NMR spectrum of the less hindered complex 3a displays the concomitant presence of both the atropoisomers in the same ratio as that found with complex 2 a (isomeric ratio $1: 6$ ), whereas the compounds $\mathbf{3 b}$ and $\mathbf{3} \mathbf{c}$ exist in solution as one single isomer (presumably the exo one).

\section{Synthesis of the $\sigma$-butadienyl isocyanide-carbene iodo- complexes}

Since the synthesis of the bromo-derivative from complex $1 \mathbf{d}$ is characterized by massive decomposition we have studied the 
reaction between complex $\mathbf{1 d}$ and $\mathrm{I}_{2}$ at RT under stoichiometric conditions. Such an approach gives the complex $\mathbf{3 d}$ as a unique reaction product. Unfortunately, owing to its intrinsic instability it was not possible to assess the structure of the complex since any attempt at growing suitable crystals failed. We therefore resorted to a DFT calculation suggesting that the isomer of 3d reported in Scheme 1 is the most stable species by about $7.2 \mathrm{kcal} \mathrm{mol}^{-1}$ with respect to the other possible isomer bearing the $\sigma$-butadienyl fragment cis to isocyanide. At variance with the previously discussed complexes $2 \mathbf{2 a - c}$ and $\mathbf{3 a - c}$, in this case the palladacyclopentadiene ring was therefore opened in the trans position to the isocyanide moiety. Complex 3d was characterized by NMR spectrometry which confirms the presence in the coordination sphere of palladium of the isocyanide and the carbene bearing the pyridine nitrogen uncoordinated. As a matter of fact the $\mathrm{H}^{6}$ pyridine proton resonates at ca. $8.6 \mathrm{ppm}$ (very near to that of the pyridine proton of the uncoordinated 1-(2-pyridyl)methylene-3-alkyl (aryl)imidazolium bromide) whereas the signals due to the isocyanide protons are clearly visible at $2.53\left(\mathrm{C}-\mathrm{CH}_{3}\right)$ and 7.17 (CH-Aryl) ppm.

The ester groups resonate as four distinct signals within 3.56-3.89 ppm whereas the carbene carbon bound to palladium is found at $163.8 \mathrm{ppm}$ (see the Experimental section).

Moreover, owing to the free rotation about the $\sigma$-bonds, the dangling pyridine and the $\sigma$-butadienyl fragment can assume a mutually perpendicular position at the same or opposite side with respect to the main coordination plane. Therefore, as can be noticed in Fig. S6 (ESI $\dagger$ and the Experimental section), the broad signals observed in the ${ }^{1} \mathrm{H}$ NMR spectrum recorded at $298 \mathrm{~K}$ duplicate at $223 \mathrm{~K}$, indicating the concomitant presence in solution of the atropoisomers endo and exo also in the case of the complex $\mathbf{3 d}$.

\section{Rearrangement of the $\sigma$-butadienyl pyridyl-carbene iodo- complexes}

At variance with the bromo-derivatives which are stable in solution for an indefinite time, iodo-complexes $\mathbf{3 a}$ and $\mathbf{3} \mathbf{b}$ in about three and twenty-eight days, respectively, undergo rearrangement to give novel derivatives whose structures were not of immediate comprehension. The rearrangement rate is clearly modulated by the steric hindrance of the carbene substituents. Thus the bulky complex $\mathbf{3 c}$ was not taken into consideration due to the slowness of its transformation. Our original interpretation about the structure of the novel species was based on our previous finding in which similar $\sigma$-butadienyl derivatives stabilized by phosphoquinoline ancillary ligands underwent a rearrangement yielding an enlargement of the primitive chelating ring (from five to six members) and the final formation of a polycyclic palladium complex. ${ }^{3 b}$ In the present case a similar rearrangement might give the compound represented in Fig. 1 whose energy calculated by the Gaussian 09 program $^{8}$ was indeed lesser than that of the original complex 3a by $9.2 \mathrm{kcal} \mathrm{mol}^{-1}$.

However, we had the definitive solution of the problem when we were able to obtain crystals suitable for X-ray diffrac-

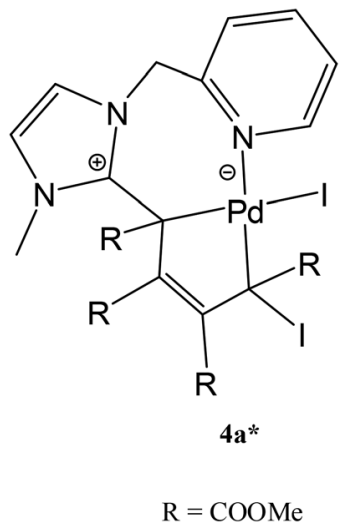

Fig. 1 Hypothetical structure (4a*) of the novel complex obtained from the rearrangement of complex $3 a$.

tometric determination. The bi-dimensional representation of the structures of the derivatives $\mathbf{4 a}$ and $\mathbf{4} \mathbf{b}$ obtained from the rearrangement of complexes 3 deduced from the X-ray structural determination of compound $\mathbf{4 b}$ are described in the following Fig. 2 whereas the authentic Pymol $^{9}$ representation of the structure of the complex $\mathbf{4 b}$ is reported in Fig. 3.

Although the coupling between an NHC carbenic carbon coordinated to a palladium and an alkylic fragment in the cis position have been already described by Danopoulos ${ }^{10}$ and Cavell's group ${ }^{11}$ it is apparent that in our case the final evolution of the rearrangement is rather unusual and the complex $\mathbf{4 b}$ is quite unexpected.

Accordingly, the DFT calculated energy for such a structure is far smaller than that of the hypothesized structure of Fig. 1 $\left(\Delta \Delta G=-24.1 \mathrm{kcal} \mathrm{mol}^{-1}\right.$; see Fig. S7 in the ESI $\left.\dagger\right)$.

The NMR spectra of complex $\mathbf{4} \mathbf{b}$ are now easily interpreted (see Fig. S8 in the ESI $\dagger$ and Experimental section) and in particular the doubling of the signals of the mesitylene ortho methyls can be traced back to the steric congestion affecting the compound.

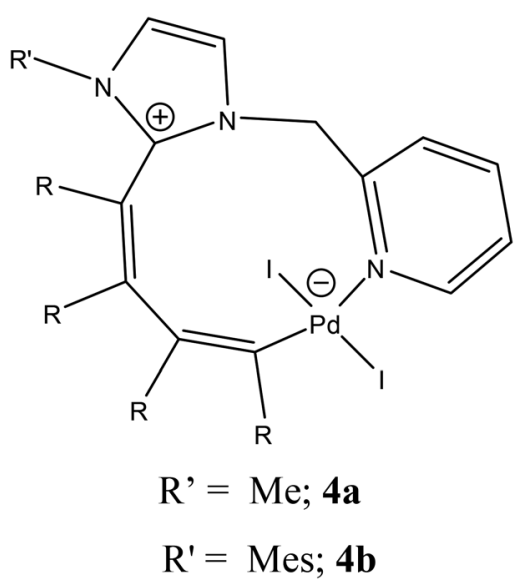

Fig. 2 Schematic representation of complex $4 a$ and $4 b$. 


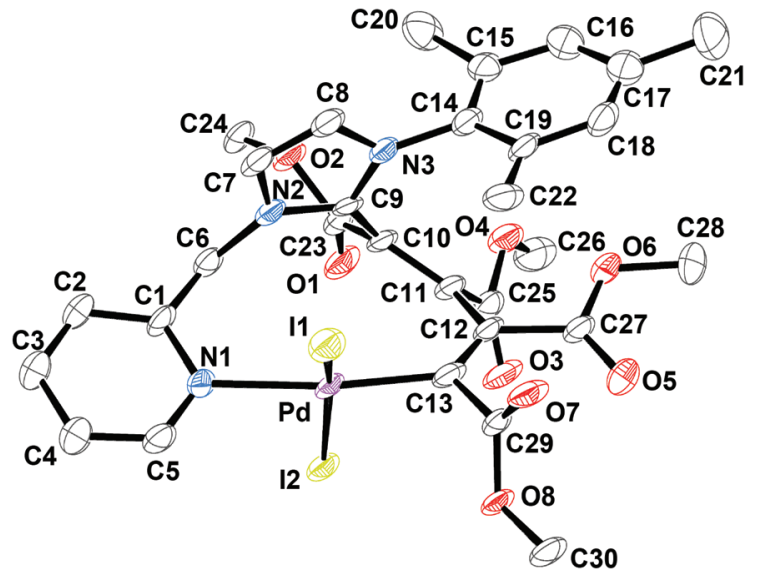

Fig. 3 Ellipsoid representation of $4 \mathrm{~b}$ (orthorhombic crystal form), ASU contents ( $50 \%$ probability).

\section{Structural characterization of complex $4 \mathrm{~b}$}

Two different crystal forms have been identified in the same batch: an orthorhombic crystal form (4b in Table 1) and a monoclinic one (4b solv in Table 1 ). Both crystal forms contain one crystallographically independent palladium complex (Fig. S9 in the ESI $\dagger$ ); the monoclinic variant shows cavities (438 $\AA^{3}$, estimated with the PLATON 'CALC VOID' routine) ${ }^{12}$ filled with disordered solvent molecules $\left(1.5 \mathrm{CH}_{2} \mathrm{Cl}_{2}\right.$ molecules for each cavity).

Overlap of complex conformations found in the two crystal forms shows almost perfect match (coordinates R.M.S.D. $0.65 \AA$ - Fig. S8 $\dagger$ ), and some packing effects can be seen on lateral carbomethoxy side chains (which are partially disordered in the orthorhombic form).

The coordination sphere of palladium shows a trans arrangement of iodine atoms with bond lengths and angle values (Table 1) in agreement with literature structural data of complexes with equivalent coordination spheres. A search of the trans $\mathrm{C}-\mathrm{PdI} 2-\mathrm{N}$ moiety led to 87 entries with average Pd-I bond lengths of 2.60(2), 2.10(3) for Pd-C and 1.96(2) $\AA$ for $\mathrm{Pd}-\mathrm{N}$. The $\mathrm{C}-\mathrm{Pd}-\mathrm{N}$ angle is in agreement with average values of previously known structures $\left(177(2)^{\circ}\right)$, while the I-Pd-I angle appears more bent in the structures reported in this work $\left(174(3)^{\circ}\right)$ on CSD compared to $164.7(1)^{\circ}$ found here, due to steric hindrance of the butadienyl based chelating ligand (Table S1, crystallographic data and refinement details in the $\mathrm{ESI}_{\dagger}^{\dagger}$ ).

\section{Kinetic study}

Owing to the favorable rate we were able to follow the rearrangement of complex 3a to $4 \mathbf{a}$ via ${ }^{1} \mathrm{H}$ NMR. A selection of the spectra of complex $\mathbf{4 b}$ is reported in Fig. S8 (ESI $\dagger$ ) whereas the concentration $v s$. time data and the related nonlinear regression based on a monoexponential model are represented in Fig. 4.

Such a model suggests a first order intramolecular rearrangement with a kinetic law described by the following expression:

$$
-\frac{\mathrm{d}[\mathbf{3 a}]}{\mathrm{d} t}=\frac{\mathrm{d}[\mathbf{4} \mathbf{a}]}{\mathrm{d} t}=k_{1}[\mathbf{3 a}]
$$

The calculated rate constant in the case of the rearrangement of complex $3 \mathrm{a}$ is $k_{1}=(2.91 \pm 0.01) \times 10^{-5} \mathrm{~s}^{-1}$, whereas the estimated rate constant for complex $3 \mathbf{b}$ is $k_{1} \approx 1.7 \times 10^{-6} \mathrm{~s}^{-1}$.

In order to reconcile the simplicity of the rate law with the probable multi-step mechanism yielding the observed complexes $\mathbf{4 a}$ or $\mathbf{4} \mathbf{b}$ we have carried out some computational investigation with the aim of determining the possible intermediates and TSs involved. In particular we have at first taken into consideration the type $\mathbf{4} \mathbf{a}^{*}$ species as possible intermediates. However, despite several attempts, no paths energetically conceivable from complex $\mathbf{3 a}$ and the intermediate $\mathbf{4} \mathbf{a}^{*}$ have been found (see Fig. S7†) suggesting that such a possibility is in the present case ruled out. Apparently, at variance with the complexes stabilized by the barely flexible phosphoquinoline

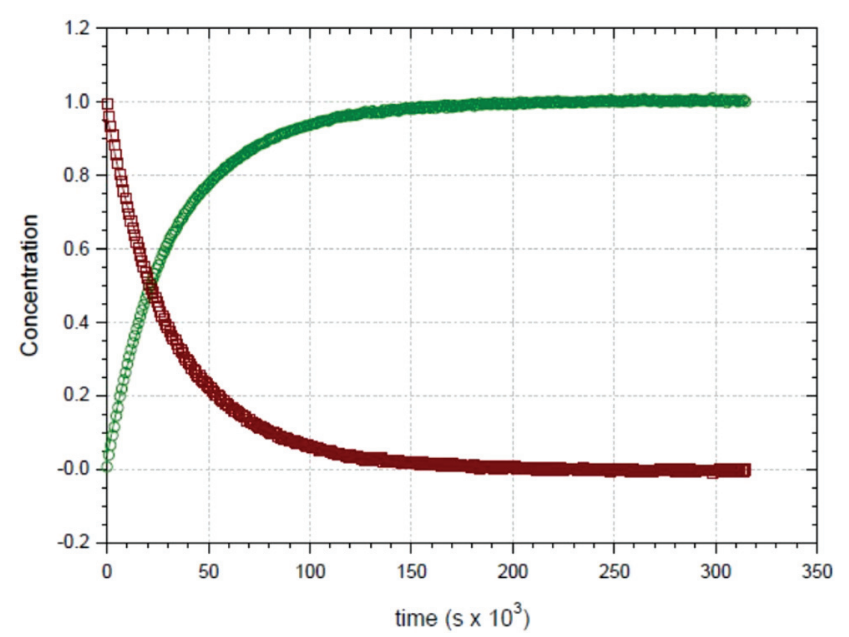

Fig. 4 Concentration profile and best fit (Scientist@) for the reaction $3 \mathrm{a} \rightarrow$ 4a monitored by ${ }^{1} \mathrm{H} \mathrm{NMR}$ in $\mathrm{CDCl}_{3}$ at $298 \mathrm{~K},[3 \mathrm{a}]_{0} \approx 1.5 \times 10^{-2}$ mol dm ${ }^{-3}$ (red squares $=[3 a]$, green circles $=[4 b]$ ).

Table 1 Selected bond distances and angles ( $\AA$ and degrees) for the polymorphs $4 \mathrm{~b}$ and $4 \mathrm{~b}$ solv

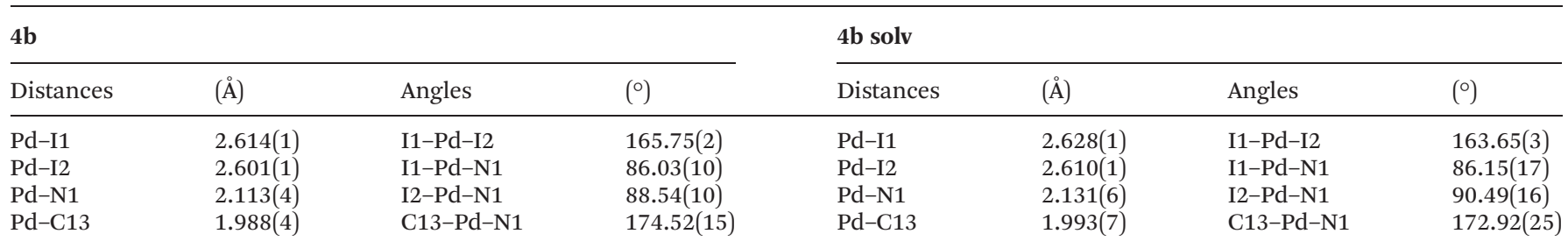




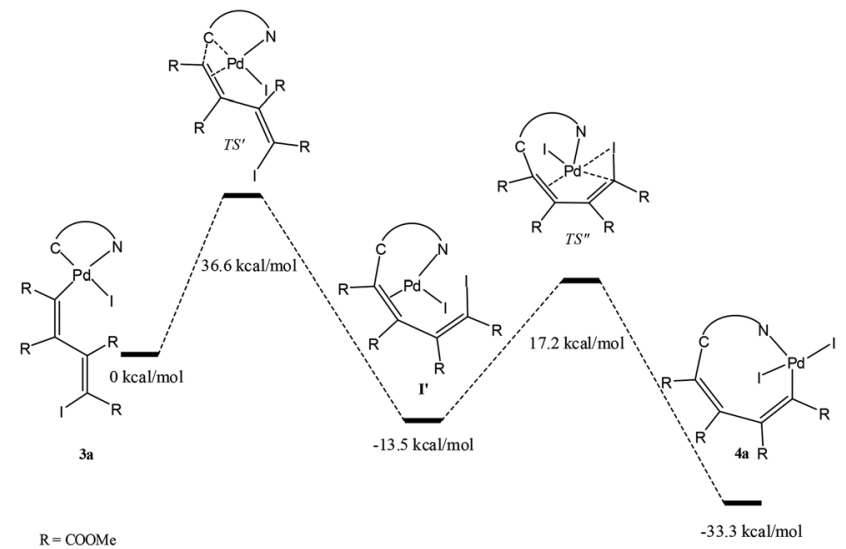

Scheme 3 Schematic profiles of the involved energies $\left(\mathrm{kcal} \mathrm{mol}^{-1}\right)$ in the rearrangement reaction of complex $3 a$ to the cyclic complex $4 a$.

ligands, ${ }^{3 b}$ the formation of the intermediate $\mathbf{4 a}^{*}$ in the present case is thermodynamically disfavored and the wider enlargement of the ring preferred (Fig. S7 in the ESI $\dagger$ ). ${ }^{13}$ The energies $\left(\Delta G\right.$ in $\mathrm{kcal} \mathrm{mol}^{-1}$ ) involved in the whole process are shown in Scheme 3 in which the formation of the $\eta^{2}$-olefin stabilized intermediate $\mathbf{I}^{\prime}$ can be represented according to Cavell's suggestion as the product of a reductive elimination. The subsequent oxidative addition at palladium of the peripheral alkyl halide represents the final detectable process giving the observed complex 4 a.

Moreover, from the energy of the TSs it is apparent that the proposed path agrees with the monoexponential decay reported in Fig. 4, the formation of the intermediate $\mathbf{I}^{\prime}$ being the rate determining step of the process.

\section{Experimental}

\section{Solvents and reagents}

All the distillation processes were carried out under an inert atmosphere (argon). $\mathrm{CH}_{2} \mathrm{Cl}_{2}$ was distilled over $\mathrm{CaH}_{2}$, acetone was dried by heating at reflux the solvent with molecular sieves $4 \mathrm{~A}$, whereas all other chemicals were commercially available grade products and were used as purchased.

\section{IR, NMR measurements and elemental analysis}

The IR, ${ }^{1} \mathrm{H}$, and ${ }^{13} \mathrm{C}$ and spectra were recorded on a PerkinElmer Spectrum One spectrophotometer and on Bruker 300 Avance or Bruker 400 spectrometers, respectively.

The ${ }^{1} \mathrm{H}$ and ${ }^{13} \mathrm{C}$ NMR spectra were obtained by dissolving the complex under study in $0.8 \mathrm{ml}$ of $\mathrm{CDCl}_{3}$ ([Complex] $\approx$ $1.2-1.5 \times 10^{-2} \mathrm{~mol} \mathrm{dm}^{-3}$ ) and recording the ensuing spectra. The reactivity tests were carried out in $\mathrm{CDCl}_{3}$ by dissolving the complexes under study ([Complex $]_{0} \approx 1.5 \times 10^{-2} \mathrm{~mol} \mathrm{dm}^{-3}$ ) and monitoring the signals for the disappearance of the starting complex and the appearance of the final products.

Elemental analyses of the synthesized complexes were carried out using an Elementar CHN "CUBO micro Vario" analyzer.

\section{Data analysis}

Nonlinear and linear analysis of the data related to kinetics measurements were performed by locally adapted routines written in ORIGIN® 7.5 or SCIENTIST® environments.

\section{Computational details}

We have undertaken a detailed computational study in order to verify the consistency, if any, between the calculated results and our experimental observations.

Remarkably, our experimental results were not in contrast with the computational study carried out by the Gaussian 09 program, ${ }^{8}$ and despite the implicit limitations $\left(\Delta \Delta G^{\circ} \approx\right.$ $\pm 2 \mathrm{kcal} \mathrm{mol}^{-1}$ ), we have obtained a confirmation and hence a possible explanation for the observed trend.

The geometrical optimization of the complexes was carried out without symmetry constraints, using the hyper-GGA functional MO6, ${ }^{14,15}$ in combination with polarized triple- $\zeta$-quality basis sets (LAN2TZ(f)) ${ }^{16,17}$ and relativistic pseudopotential for the Pd atoms, polarized double- $\zeta$-quality basis sets (LANL2DZdp) ${ }^{18}$ with diffuse functions for the halogen atoms and polarized double- $\zeta$-quality basis sets $(6-31 G(d, p))$ for the other elements. Solvent effects $\left(\mathrm{CH}_{2} \mathrm{Cl}_{2}, \varepsilon=8.93\right)$ were included using CPCM. ${ }^{19,20}$

The "restricted" formalism was applied in all the calculations. The zero-point vibrational energies and thermodynamic parameters were obtained ${ }^{21}$ by means of the stationary points characterized by IR simulation.

All the computational work was carried out on Intel based x86-64 workstations.

\section{Crystal structure determinations}

The crystal data of two polymorphs of compound 1 were collected at $100 \mathrm{~K}$ at the XRD1 beamline of the Elettra Synchrotron, Trieste (Italy). ${ }^{22}$ The data sets were integrated and corrected for Lorentz and polarization effects with the XDS package. ${ }^{23}$ Semi-empirical absorption corrections and scaling were performed using the SADABS program. ${ }^{24}$ The structures were solved by direct methods using the SHELXT program $^{25}$ and refined using full-matrix least-squares with all non-hydrogen atoms anisotropically and hydrogens included on calculated positions, riding on their carrier atoms. Geometric restraints on bond lengths and angles (DFIX, DANG) have been used for disordered fragments (solvent molecules in $\mathbf{4 b}$ solv and some carbomethoxy side groups in 4b). All calculations were performed using SHELXL-2016. ${ }^{26}$ The Coot program was used for structure building. ${ }^{27}$ The crystal data are given in Table S1. $\dagger$ Pictures were prepared using Pymol ${ }^{9}$ and Ortep ${ }^{28}$ software (Fig. S10: ORTEP representation in the ESI $\dagger$ ).

Crystallographic data have been deposited at the Cambridge Crystallographic Data Centre and allocated the deposition numbers CCDC 1554851 (4b) and1554852 (4b solv). $\dagger$

\section{Synthesis of the complexes}

Complexes 1a-d have been synthesized according to published procedures. $^{7}$ 


\section{Synthesis of complex 2a}

To $0.04 \mathrm{~g}$ (0.071 mmol) of complex 1a dissolved in $c a .15 \mathrm{ml}$ of anhydrous $\mathrm{CH}_{2} \mathrm{Cl}_{2}$ in a two-necked $100 \mathrm{ml}$ flask refrigerated with an ice bath, $0.0136 \mathrm{~g}(0.085 \mathrm{mmol})$ of $\mathrm{Br}_{2}$ dissolved in a small quantity of anhydrous $\mathrm{CH}_{2} \mathrm{Cl}_{2}$ was added under an inert atmosphere $(\mathrm{Ar})$. The reaction mixture was stirred for ca. $10 \mathrm{~min}$ and evaporated to a small volume under vacuum. The addition of diethyl ether induces the precipitation of the pale yellow complex $2 \mathrm{a}$ which was filtered off on a gooch, repeatedly washed with diethyl ether and finally dried under vacuum. $0.0427 \mathrm{~g}$ (yield 83\%) of the complex $2 \mathrm{a}$ was obtained.

${ }^{1} \mathbf{H}$ NMR $\left(\mathrm{CDCl}_{3}, T=298 \mathrm{~K}, \mathrm{ppm}\right)$, (most abundant isomer $85 \%), \delta: 3.70\left(\mathrm{~s}, 3 \mathrm{H}, \mathrm{OCH}_{3}\right), 3.83\left(\mathrm{~s}, 3 \mathrm{H}, \mathrm{OCH}_{3}\right), 3.85(\mathrm{~s}, 3 \mathrm{H}$, $\left.\mathrm{OCH}_{3}\right), 3.89\left(\mathrm{~s}, 3 \mathrm{H}, \mathrm{OCH}_{3}\right), 4.07$ (s, 3H, $\left.\mathrm{NCH}_{3}\right), 4.89$ (d, $J=15.0$ $\mathrm{Hz}, 1 \mathrm{H}, \mathrm{NCH}_{2}$ ), 6.15 (d, $J=15.0 \mathrm{~Hz}, 1 \mathrm{H}, \mathrm{NCH}_{2}$ ), 6.76 (d, 1H, $J=$ $1.6 \mathrm{~Hz}, \mathrm{CH}=\mathrm{CH} \mathrm{Im}), 7.13(\mathrm{~d}, 1 \mathrm{H}, J=1.6 \mathrm{~Hz}, \mathrm{CH}=\mathrm{CH} \mathrm{Im}), 7.33$ (dd, $J=7.6,4.9 \mathrm{~Hz}, 1 \mathrm{H}, 5$-Pyr), 7.39 (d, $J=7.7 \mathrm{~Hz}, 1 \mathrm{H}, 3-\mathrm{Pyr}$ ), $7.79(\mathrm{td}, J=7.6,1.5 \mathrm{~Hz}, 1 \mathrm{H}, 4-\mathrm{Pyr}), 9.27$ (d, $J=4.9 \mathrm{~Hz}, 1 \mathrm{H}$, 6-Pyr).

(Less abundant isomer 15\%) $\delta: 3.52\left(\mathrm{~s}, 3 \mathrm{H}, \mathrm{OCH}_{3}\right), 3.64(\mathrm{~s}$, $\left.3 \mathrm{H}, \mathrm{OCH}_{3}\right), 3.88\left(\mathrm{~s}, 3 \mathrm{H}, \mathrm{OCH}_{3}\right), 3.90\left(\mathrm{~s}, 3 \mathrm{H}, \mathrm{OCH}_{3}\right), 3.97(\mathrm{~s}, 3 \mathrm{H}$, $\mathrm{NCH}_{3}$ ), 4.94 (d, $\left.J=15.1 \mathrm{~Hz}, 1 \mathrm{H}, \mathrm{NCH}_{2}\right), 6.06$ (d, $J=15.0 \mathrm{~Hz}$, $1 \mathrm{H}, \mathrm{NCH}_{2}$ ), 6.75 (bs, $\left.1 \mathrm{H}, \mathrm{CH}=\mathrm{CH} \mathrm{Im}\right), 7.04$ (bs, $1 \mathrm{H}, \mathrm{CH}=\mathrm{CH}$ Im), 7.33 (dd, $J=7.6,4.9 \mathrm{~Hz}, 1 \mathrm{H}, 5$-Pyr), 7.39 (d, $J=7.7 \mathrm{~Hz}, 1 \mathrm{H}$, 3-Pyr), 7.79 (td, $J=7.6,1.5 \mathrm{~Hz}, 1 \mathrm{H}, 4-\mathrm{Pyr}), 9.41$ (d, $J=4.9 \mathrm{~Hz}$, 1H, 6-Pyr).

${ }^{13} \mathbf{C}\left\{{ }^{\mathbf{1}} \mathbf{H}\right\}$ NMR $\left(\mathrm{CDCl}_{3}, T=298 \mathrm{~K}, \mathrm{ppm}\right)($ most abundant isomer 85\%) $\delta$ : $38.6\left(\mathrm{CH}_{3}, \mathrm{NCH}_{3}\right), 51.8\left(\mathrm{CH}_{3}, \mathrm{OCH}_{3}\right), 52.0\left(\mathrm{CH}_{3}\right.$, $\left.\mathrm{OCH}_{3}\right), 53.3\left(\mathrm{CH}_{3}, \mathrm{OCH}_{3}\right), 54.0\left(\mathrm{CH}_{3}, \mathrm{OCH}_{3}\right), 54.5\left(\mathrm{CH}_{2}, \mathrm{NCH}_{2}\right)$, $120.7(\mathrm{C}, \mathrm{C}=\mathrm{C}-\mathrm{Br}), 121.2(\mathrm{CH}, \mathrm{CH}=\mathrm{CH} \mathrm{Im}), 122.1(\mathrm{CH}$, $\mathrm{CH}=\mathrm{CH} \mathrm{Im}$ ), 123.3 (CH, 3-Pyr), 124.5 (CH, 5-Pyr), 129.9 (C, $\mathrm{C}=\mathrm{C}$ ), 138.8 ( $\mathrm{CH}, 4-\mathrm{Pyr}), 139.3$ (C, C=C), 152.9 (C, 2-Pyr), 154.9 (CH, 6-Pyr), 161.3 (C, C=O), 164.0 (C, NCN), 165.1 (C, $\mathrm{C}=\mathrm{O}), 166.4(\mathrm{C}, \mathrm{C}=\mathrm{O}), 167.2(\mathrm{C}, \mathrm{C}=\mathrm{C}), 173.8(\mathrm{C}, \mathrm{C}=\mathrm{O})$.

IR (KBr pellets): $\nu_{\mathrm{C}=\mathrm{O}}: 1703 \mathrm{~cm}^{-1}, \nu_{\mathrm{C}-\mathrm{O}}: 1227 \mathrm{~cm}^{-1}$.

Elemental anal. (\%) for $\mathrm{C}_{22} \mathrm{H}_{23} \mathrm{Br}_{2} \mathrm{~N}_{3} \mathrm{O}_{8} \mathrm{Pd}$ : C 36.51, H 3.20, N 5.81. Found: C 36.68, H 3.33, N 5.75.

Complexes $\mathbf{2 b - c}$ were obtained according to the above described protocols using the appropriate starting complexes and $\mathrm{Br}_{2}$. The yield, color, reaction time and, where necessary, some supplementary information will be reported below the title.

\section{Synthesis of complex $2 b$}

Reaction time: $10 \mathrm{~min}$. Temperature: $0{ }^{\circ} \mathrm{C}$. Yield 86\%. Color: pale yellow.

${ }^{1} \mathrm{H}$ NMR $\left(\mathrm{CD}_{2} \mathrm{Cl}_{2}, T=298 \mathrm{~K}, \mathrm{ppm}\right), \delta: 1.62$ (s, 3H, o-mesityl$\mathrm{CH}_{3}$ ), 2.32 (s, 3H, o-mesityl- $\mathrm{CH}_{3}$ ), 2.37 (s, 3H, p-mesityl- $\mathrm{CH}_{3}$ ), $3.31\left(\mathrm{~s}, 3 \mathrm{H}, \mathrm{OCH}_{3}\right), 3.64\left(\mathrm{~s}, 3 \mathrm{H}, \mathrm{OCH}_{3}\right), 3.75\left(\mathrm{~s}, 3 \mathrm{H}, \mathrm{OCH}_{3}\right)$, $3.90\left(\mathrm{~s}, 3 \mathrm{H}, \mathrm{OCH}_{3}\right), 5.12\left(\mathrm{~d}, J=15.2 \mathrm{~Hz}, 1 \mathrm{H}, \mathrm{NCH}_{2}\right), 6.51(\mathrm{~d}, J=$ $15.2 \mathrm{~Hz}, 1 \mathrm{H}, \mathrm{NCH}_{2}$ ), 6.73 (d, $\left.J=1.6 \mathrm{~Hz}, 1 \mathrm{H}, \mathrm{CH}=\mathrm{CH} \mathrm{Im}\right), 6.90$ (s, 1H, m-mesityl-H), 7.04 (s, 1H, m-mesityl-H), 7.28-7.34 (m, $2 \mathrm{H}, \mathrm{CH}=\mathrm{CH} \mathrm{Im}, 5-\mathrm{Pyr}), 7.48$ (d, $J=7.6 \mathrm{~Hz}, 1 \mathrm{H}, 3-\mathrm{Pyr}), 7.82(\mathrm{t}$, $J=7.6 \mathrm{~Hz}, 1 \mathrm{H}, 4-\mathrm{Pyr}$ ), 9.13 (d, $J=4.9 \mathrm{~Hz}, 1 \mathrm{H}, 6-\mathrm{Pyr})$.

${ }^{13} \mathbf{C}\left\{{ }^{1} \mathbf{H}\right\}$ NMR $\left(\mathrm{CD}_{2} \mathrm{Cl}_{2}, T=298 \mathrm{~K}, \mathrm{ppm}\right), \delta: 18.5\left(\mathrm{CH}_{3}\right.$, $o$-mesityl- $\left.\mathrm{CH}_{3}\right), 19.4\left(\mathrm{CH}_{3}, p\right.$-mesityl- $\left.\mathrm{CH}_{3}\right), 21.0\left(\mathrm{CH}_{3}, o\right.$-mesityl-
$\left.\mathrm{CH}_{3}\right), 51.4\left(\mathrm{CH}_{3}, \mathrm{OCH}_{3}\right), 51.8\left(\mathrm{CH}_{3}, \mathrm{OCH}_{3}\right), 53.5\left(\mathrm{CH}_{3}, \mathrm{OCH}_{3}\right)$, $53.6\left(\mathrm{CH}_{3}, \mathrm{OCH}_{3}\right), 56.8\left(\mathrm{CH}_{2}, \mathrm{NCH}_{2}\right), 121.5(\mathrm{CH}, \mathrm{CH}=\mathrm{CH} \mathrm{Im})$, $123.4(\mathrm{CH}, \mathrm{CH}=\mathrm{CH} \mathrm{Im}), 123.7$ (CH, 3-Pyr), 124.7 (CH, 5-Pyr), 128.8 (CH, m-mesityl), 129.1 (C, i-mesityl), $129.6(\mathrm{CH}$, m-mesityl), 134.8 (C, o-mesityl), 135.3 (C, o-mesityl), 135.5 (C, p-mesityl), 138.9 (CH, 4-Pyr), 153.2 (C, 2-Pyr), 154.2 (CH, 6-Pyr), $160.8(\mathrm{C}, \mathrm{C}=\mathrm{O}), 165.5(\mathrm{C}, \mathrm{C}=\mathrm{O}) 166.1(\mathrm{C}, \mathrm{C}=\mathrm{O}), 166.5$ (C, $\mathrm{C}=\mathrm{C}), 169.3(\mathrm{C}, \mathrm{NCN}), 170.7(\mathrm{C}, \mathrm{C}=\mathrm{O})$.

IR (KBr pellets): $\nu_{\mathrm{C}=\mathrm{O}}: 1711 \mathrm{~cm}^{-1}, \nu_{\mathrm{C}-\mathrm{O}}: 1233 \mathrm{~cm}^{-1}$.

Elemental anal. (\%) for $\mathrm{C}_{30} \mathrm{H}_{31} \mathrm{Br}_{2} \mathrm{~N}_{3} \mathrm{O}_{8} \mathrm{Pd}$ : C 43.53, H 3.77, N 5.08. Found: C 43.38, H 3.89, N 4.91.

\section{Synthesis of complex 2c}

Reaction time: $10 \mathrm{~min}$. Temperature: $0^{\circ} \mathrm{C}$. Yield 90\%. Color: pale yellow.

${ }^{1} \mathbf{H}$ NMR $\left(\mathrm{CDCl}_{3}, T=298 \mathrm{~K}, \mathrm{ppm}\right), \delta: 0.58(\mathrm{~d}, J=6.8 \mathrm{~Hz}, 3 \mathrm{H}$, iPr- $\mathrm{CH}_{3}$ ), 1.19 (d, $\left.J=6.8 \mathrm{~Hz}, 3 \mathrm{H}, \mathrm{iPr}-\mathrm{CH}_{3}\right), 1.25$ (d, $J=6.8 \mathrm{~Hz}$, $3 \mathrm{H}, \mathrm{iPr}-\mathrm{CH}_{3}$ ), 1.58 (d, $J=6.8 \mathrm{~Hz}, 3 \mathrm{H}, \mathrm{iPr}-\mathrm{CH}_{3}$ ), 2.06 (sept, $1 \mathrm{H}$, $J=6.8 \mathrm{~Hz}$, iPr-CH), 3.08 (sept, $1 \mathrm{H}, J=6.8 \mathrm{~Hz}, \mathrm{iPr}-\mathrm{CH}), 3.08$ (s, $\left.3 \mathrm{H}, \mathrm{OCH}_{3}\right), 3.27\left(\mathrm{~s}, 3 \mathrm{H}, \mathrm{OCH}_{3}\right), 3.78\left(\mathrm{~s}, 3 \mathrm{H}, \mathrm{OCH}_{3}\right), 3.90(\mathrm{~s}, 3 \mathrm{H}$, $\left.\mathrm{OCH}_{3}\right), 5.14$ (d, $\left.J=15.0 \mathrm{~Hz}, 1 \mathrm{H}, \mathrm{NCH}_{2}\right), 6.62$ (d, $J=15.2 \mathrm{~Hz}$, $\left.1 \mathrm{H}, \mathrm{NCH}_{2}\right), 6.76(\mathrm{~d}, J=1.8 \mathrm{~Hz}, 1 \mathrm{H}, \mathrm{CH}=\mathrm{CH} \mathrm{Im}), 7.23-7.52(\mathrm{~m}$, $6 \mathrm{H}, m$-aryl-H, $p$-aryl-H, 2H, $\mathrm{CH}=\mathrm{CH} \mathrm{Im}, 5-\mathrm{Pyr}, 3-\mathrm{Pyr}), 7.84(\mathrm{t}$, $J=7.7 \mathrm{~Hz}, 1 \mathrm{H}, 4-\mathrm{Pyr}$ ), 9.15 (d, $J=5.2 \mathrm{~Hz}, 1 \mathrm{H}, 6-\mathrm{Pyr}$ ).

${ }^{13} \mathbf{C}\left\{{ }^{1} \mathbf{H}\right\}$ NMR $\left(\mathrm{CDCl}_{3}, T=298 \mathrm{~K}, \mathrm{ppm}\right), \delta: 23.2\left(\mathrm{CH}_{3}\right.$, iPr$\left.\mathrm{CH}_{3}\right), 24.6\left(\mathrm{CH}_{3}\right.$, iPr- $\left.\mathrm{CH}_{3}\right), 24.8\left(\mathrm{CH}_{3}, \mathrm{iPr}-\mathrm{CH}_{3}\right), 25.8\left(\mathrm{CH}_{3}\right.$, iPr$\left.\mathrm{CH}_{3}\right), 28.4\left(\mathrm{CH}\right.$, iPr-CH), $28.6\left(\mathrm{CH}_{3}, \mathrm{iPr}-\mathrm{CH}_{3}\right), 51.2\left(\mathrm{CH}_{3}\right.$, $\left.\mathrm{OCH}_{3}\right), 51.7\left(\mathrm{CH}_{3}, \mathrm{OCH}_{3}\right), 53.5\left(\mathrm{CH}_{3}, \mathrm{OCH}_{3}\right), 53.7\left(\mathrm{CH}_{3}, \mathrm{OCH}_{3}\right)$, $56.8\left(\mathrm{CH}_{2}, \mathrm{NCH}_{2}\right), 121.1(\mathrm{CH}, \mathrm{CH}=\mathrm{CH} \mathrm{Im}), 122.2(\mathrm{C}, \mathrm{C}=\mathrm{CBr})$, 123.3 (CH, 3-Pyr), 123.9 (CH, 5-Pyr), 124.3 (CH, m-Ph), 124.8 (CH, $m$-Ph), $125.3(\mathrm{CH}, \mathrm{CH}=\mathrm{CH} \mathrm{Im}), 129.9(\mathrm{CH}, p-\mathrm{Ph}), 134.7$ (C, i-Ph), 139.0 (CH, 4-Pyr), 139.5 (C, C=C), $145.4(\mathrm{C}, \mathrm{C}=\mathrm{C})$, 145.5 (C, o-Ph), 153.3 (C, 2-Pyr), 154.1 (CH, 6-Pyr), 159.8 (C, $\mathrm{C}=\mathrm{O}), 166.9(\mathrm{C}, \mathrm{C}=\mathrm{C}), 166.1(\mathrm{C}, \mathrm{C}=\mathrm{O}), 166.9(\mathrm{C}, \mathrm{C}=\mathrm{O}), 169.4$ (C, NCN).170.5 (C, C=O).

IR (KBr pellets): $\nu_{\mathrm{C}=\mathrm{O}}: 1714 \mathrm{~cm}^{-1}, \nu_{\mathrm{C}-\mathrm{O}}: 1233 \mathrm{~cm}^{-1}$.

Elemental anal. (\%) for $\mathrm{C}_{33} \mathrm{H}_{37} \mathrm{Br}_{2} \mathrm{~N}_{3} \mathrm{O}_{8} \mathrm{Pd}$ : $\mathrm{C} 45.56, \mathrm{H} 4.29$, $\mathrm{N}$ 4.83. Found: $\mathrm{C} 45.44, \mathrm{H} 4.23, \mathrm{~N} 4.97$.

\section{Synthesis of complex 3a}

To $0.0958 \mathrm{~g}(0.170 \mathrm{mmol})$ of complex 1a dissolved in ca. $20 \mathrm{ml}$ of anhydrous $\mathrm{CH}_{2} \mathrm{Cl}_{2}$ in a two-necked $100 \mathrm{ml}$ flask refrigerated with an ice bath, $0.0517 \mathrm{~g}(0.204 \mathrm{mmol})$ of $\mathrm{I}_{2}$ dissolved in a small quantity of anhydrous $\mathrm{CH}_{2} \mathrm{Cl}_{2}$ was added under an inert atmosphere (Ar). The reaction mixture was stirred for ca. $10 \mathrm{~min}$ and evaporated to a small volume under vacuum. The addition of diethyl ether induces the precipitation of the orange complex 3a which was filtered off on a gooch, repeatedly washed with diethyl ether and finally dried under vacuum. $0.1316 \mathrm{~g}$ (yield 95\%) of the complex 3a was obtained.

${ }^{1} \mathbf{H}$ NMR $\left(\mathrm{CDCl}_{3}, T=298 \mathrm{~K}, \mathrm{ppm}\right)$, (most abundant isomer $85 \%), \delta: 3.70\left(\mathrm{~s}, 3 \mathrm{H}, \mathrm{OCH}_{3}\right), 3.82\left(\mathrm{~s}, 3 \mathrm{H}, \mathrm{OCH}_{3}\right), 3.86(\mathrm{~s}, 3 \mathrm{H}$, $\left.\mathrm{OCH}_{3}\right), 3.88\left(\mathrm{~s}, 3 \mathrm{H}, \mathrm{OCH}_{3}\right), 4.13\left(\mathrm{~s}, 3 \mathrm{H}, \mathrm{NCH}_{3}\right), 4.87$ (d, $J=15.0$ $\mathrm{Hz}, 1 \mathrm{H}, \mathrm{NCH}_{2}$ ), 6.23 (d, $\left.J=15.0 \mathrm{~Hz}, 1 \mathrm{H}, \mathrm{NCH}_{2}\right), 6.76$ (d, $J=1.8$ $\mathrm{Hz}, 1 \mathrm{H}, \mathrm{CH}=\mathrm{CH} \mathrm{Im}), 7.11(\mathrm{~d}, J=1.8 \mathrm{~Hz}, 1 \mathrm{H}, \mathrm{CH}=\mathrm{CH} \mathrm{Im})$, 
7.28 (m, 1H, 5-Pyr), 7.37 (d, $J=7.7 \mathrm{~Hz}, 1 \mathrm{H}, 3-\mathrm{Pyr}), 7.78$ (td, $J=$ 7.7, 1.6 Hz, 1H, 4-Pyr), 9.44 (d, $J=4.9$ Hz, 1H, 6-Pyr).

(Less abundant isomer 15\%), $\delta: 3.49\left(\mathrm{~s}, 3 \mathrm{H}, \mathrm{OCH}_{3}\right), 3.64(\mathrm{~s}$, $\left.3 \mathrm{H}, \mathrm{OCH}_{3}\right), 3.87\left(\mathrm{~s}, 3 \mathrm{H}, \mathrm{OCH}_{3}\right), 3.88\left(\mathrm{~s}, 3 \mathrm{H}, \mathrm{OCH}_{3}\right), 3.96(\mathrm{~s}, 3 \mathrm{H}$, $\left.\mathrm{NCH}_{3}\right), 4.91$ (d, $\left.J=15.0 \mathrm{~Hz}, 1 \mathrm{H}, \mathrm{NCH}_{2}\right), 6.08$ (d, $J=15.0 \mathrm{~Hz}$, $\left.1 \mathrm{H}, \mathrm{NCH}_{2}\right), 6.68(\mathrm{~d}, J=1.8 \mathrm{~Hz}, 1 \mathrm{H}, \mathrm{CH}=\mathrm{CH} \mathrm{Im}), 7.00(\mathrm{~d}, J=$ $1.8 \mathrm{~Hz}, 1 \mathrm{H}, \mathrm{CH}=\mathrm{CH} \mathrm{Im}), 7.28(\mathrm{~m}, 1 \mathrm{H}, 5-\mathrm{Pyr}), 7.38(\mathrm{~d}, J=$ $7.7 \mathrm{~Hz}, 1 \mathrm{H}, 3-\mathrm{Pyr}$ ), 7.80 (td, $J=7.7,1.6 \mathrm{~Hz}, 1 \mathrm{H}, 4-\mathrm{Pyr}), 9.64$ (d, $J=4.9 \mathrm{~Hz}, 1 \mathrm{H}, 6-\mathrm{Pyr})$.

${ }^{13} \mathbf{C}\left\{{ }^{1} \mathbf{H}\right\}$ NMR $\left(\mathrm{CDCl}_{3}, T=253 \mathrm{~K}, \mathrm{ppm}\right)$, (most abundant isomer 85\%), $\delta$ : $38.6\left(\mathrm{CH}_{3}, \mathrm{NCH}_{3}\right), 52.1\left(\mathrm{CH}_{3}, \mathrm{OCH}_{3}\right), 52.4$ $\left(\mathrm{CH}_{3}, \mathrm{OCH}_{3}\right), 53.7\left(\mathrm{CH}_{3}, \mathrm{OCH}_{3}\right), 54.7\left(\mathrm{CH}_{3}, \mathrm{OCH}_{3}\right), 55.5\left(\mathrm{CH}_{2}\right.$, $\left.\mathrm{NCH}_{2}\right), 100.2(\mathrm{C}, \mathrm{C}=\mathrm{C}-\mathrm{I}), 121.1(\mathrm{CH}, \mathrm{CH}=\mathrm{CH} \mathrm{Im}), 122.2(\mathrm{CH}$, $\mathrm{CH}=\mathrm{CH}$ Im), 123.7 (CH, 5-Pyr), 124.5 (CH, 3-Pyr), 131.6 (C, $\mathrm{C}=\mathrm{C}$ ), 138.9 ( $\mathrm{CH}, 4-\mathrm{Pyr}), 143.9$ (C, C=C), 153.1 (C, 2-Pyr), 156.6 (CH, 6-Pyr), 160.7 (C, C=O), 165.1 (C, C=O), 165.8 (C, $\mathrm{NCN}), 166.3(\mathrm{C}, \mathrm{C}=\mathrm{O}), 167.1(\mathrm{C}, \mathrm{C}=\mathrm{C}), 174.3(\mathrm{C}, \mathrm{C}=\mathrm{O})$.

IR (KBr pellets): $\nu_{\mathrm{C}=\mathrm{O}}: 1703 \mathrm{~cm}^{-1}, \nu_{\mathrm{C}-\mathrm{O}}: 1225 \mathrm{~cm}^{-1}$.

Elemental anal. (\%) for $\mathrm{C}_{22} \mathrm{H}_{23} \mathrm{I}_{2} \mathrm{~N}_{3} \mathrm{O}_{8} \mathrm{Pd}$ : C 32.32, $\mathrm{H}$ 2.84, N 5.14. Found: C 32.47, H 2.79, N 5.18.

Complexes $\mathbf{3 b}$-d were obtained according to the above described protocols using the appropriate starting complexes and $\mathrm{I}_{2}$. The yield, color, reaction time and, where necessary, some supplementary information will be reported below the title.

\section{Synthesis of complex $3 \mathbf{b}$}

Reaction time: $10 \mathrm{~min}$. Temperature: $0{ }^{\circ} \mathrm{C}$. Yield 95\%. Color: orange.

${ }^{1} \mathrm{H}$ NMR $\left(\mathrm{CD}_{2} \mathrm{Cl}_{2}, T=298 \mathrm{~K}, \mathrm{ppm}\right), \delta: 1.60$ (s, 3H, o-mesityl$\mathrm{CH}_{3}$ ), 2.37 (s, 3H, o-mesityl- $\mathrm{CH}_{3}$ ), 2.40 (s, 3H, p-mesityl- $\mathrm{CH}_{3}$ ), $3.24\left(\mathrm{~s}, 3 \mathrm{H}, \mathrm{OCH}_{3}\right), 3.62\left(\mathrm{~s}, 3 \mathrm{H}, \mathrm{OCH}_{3}\right), 3.70\left(\mathrm{~s}, 3 \mathrm{H}, \mathrm{OCH}_{3}\right)$, $3.89\left(\mathrm{~s}, 3 \mathrm{H}, \mathrm{OCH}_{3}\right), 5.12\left(\mathrm{~d}, J=15.2 \mathrm{~Hz}, 1 \mathrm{H}, \mathrm{NCH}_{2}\right), 6.49$ (d, $J=$ $15.2 \mathrm{~Hz}, 1 \mathrm{H}, \mathrm{NCH}_{2}$ ), 6.77 (d, $\left.J=1.8 \mathrm{~Hz}, 1 \mathrm{H}, \mathrm{CH}=\mathrm{CH} \mathrm{Im}\right), 7.00$ (s, 1H, m-mesityl-H), 7.06 (s, 1H, m-mesityl-H), 7.33-7.37 (m, $2 \mathrm{H}, \mathrm{CH}=\mathrm{CH} \mathrm{Im}, 5-\mathrm{Pyr}), 7.53$ (d, $J=7.7 \mathrm{~Hz}, 1 \mathrm{H}, 3-\mathrm{Pyr}), 7.87$ (t, $J=7.7 \mathrm{~Hz}, 1 \mathrm{H}, 4$-Pyr), 9.32 (d, $J=4.5 \mathrm{~Hz}, 1 \mathrm{H}, 6$-Pyr).

${ }^{13} \mathbf{C}\left\{{ }^{1} \mathbf{H}\right\}$ NMR $\left(\mathrm{CD}_{2} \mathrm{Cl}_{2}, T=298 \mathrm{~K}, \mathrm{ppm}\right), \delta: 18.7\left(\mathrm{CH}_{3}\right.$, $o$-mesityl- $\left.\mathrm{CH}_{3}\right), 20.9\left(\mathrm{CH}_{3}, o\right.$-mesityl- $\left.\mathrm{CH}_{3}\right), 21.0\left(\mathrm{CH}_{3}, p\right.$-mesityl$\left.\mathrm{CH}_{3}\right), 51.6\left(\mathrm{CH}_{3}, \mathrm{OCH}_{3}\right), 51.9\left(\mathrm{CH}_{3}, \mathrm{OCH}_{3}\right), 53.6\left(\mathrm{CH}_{3}, \mathrm{OCH}_{3}\right)$, $53.8\left(\mathrm{CH}_{3}, \mathrm{OCH}_{3}\right), 57.0\left(\mathrm{CH}_{2}, \mathrm{NCH}_{2}\right), 101.4(\mathrm{C}, \mathrm{C}=\mathrm{C}-\mathrm{I}), 121.4$ $(\mathrm{CH}, \mathrm{CH}=\mathrm{CH} \mathrm{Im}), 122.7(\mathrm{CH}, \mathrm{CH}=\mathrm{CH} \mathrm{Im}), 123.8$ (CH, 3-Pyr), 124.9 (CH, 5-Pyr), 129.1 (CH, m-mesityl), 129.6 (CH, m-mesityl), 134.8 (C, o-mesityl), 135.2 (C, o-mesityl), 135.4 (C, p-mesityl), 139.0 (CH, 4-Pyr), 153.4 (C, 2-Pyr), 156.1 (CH, 6-Pyr), $160.2(\mathrm{C}, \mathrm{C}=\mathrm{O}), 165.4(\mathrm{C}, \mathrm{C}=\mathrm{O}), 167.9(\mathrm{C}, \mathrm{C}=\mathrm{O}), 170.3$ (C, $\mathrm{NCN}), 170.7(\mathrm{C}, \mathrm{C}=\mathrm{O})$.

IR (KBr pellets): $\nu_{\mathrm{C}=\mathrm{O}}: 1711 \mathrm{~cm}^{-1}, \nu_{\mathrm{C}-\mathrm{O}}: 1233 \mathrm{~cm}^{-1}$.

Elemental anal. (\%) for $\mathrm{C}_{30} \mathrm{H}_{31} \mathrm{I}_{2} \mathrm{~N}_{3} \mathrm{O}_{8} \mathrm{Pd}$ : C 39.09, H 3.39, $\mathrm{N}$ 4.56. Found: C 39.22, H 3.52, N 4.41.

\section{Synthesis of complex $3 \mathrm{c}$}

Reaction time: 10 min. Temperature: $0{ }^{\circ} \mathrm{C}$. Yield 95\%. Color: orange.

${ }^{1} \mathbf{H}$ NMR $\left(\mathrm{CDCl}_{3}, T=298 \mathrm{~K}, \mathrm{ppm}\right), \delta: 0.52(\mathrm{~d}, J=6.8 \mathrm{~Hz}, 3 \mathrm{H}$, iPr- $\mathrm{CH}_{3}$ ), 1.18 (d, $\left.J=6.8 \mathrm{~Hz}, 3 \mathrm{H}, \mathrm{iPr}-\mathrm{CH}_{3}\right), 1.27$ (d, $J=6.8 \mathrm{~Hz}$,
$3 \mathrm{H}, \mathrm{iPr}-\mathrm{CH}_{3}$ ), 1.56 (d, $J=6.8 \mathrm{~Hz}, 3 \mathrm{H}, \mathrm{iPr}-\mathrm{CH}_{3}$ ), 2.11 (sept, $1 \mathrm{H}$, $J=6.8 \mathrm{~Hz}$, iPr-CH), $3.18\left(\mathrm{~s}, 3 \mathrm{H}, \mathrm{OCH}_{3}\right), 3.24$ (sept, $1 \mathrm{H}, J=$ $6.8 \mathrm{~Hz}$, iPr-CH), $3.61\left(\mathrm{~s}, 3 \mathrm{H}, \mathrm{OCH}_{3}\right), 3.79\left(\mathrm{~s}, 3 \mathrm{H}, \mathrm{OCH}_{3}\right), 3.88(\mathrm{~s}$, $\left.3 \mathrm{H}, \mathrm{OCH}_{3}\right), 5.19\left(\mathrm{~d}, J=15.1 \mathrm{~Hz}, 1 \mathrm{H}, \mathrm{NCH}_{2}\right), 6.66(\mathrm{~d}, J=15.2 \mathrm{~Hz}$, $1 \mathrm{H}, \mathrm{NCH}_{2}$ ), 6.75 (d, $\left.J=1.8 \mathrm{~Hz}, 1 \mathrm{H}, \mathrm{CH}=\mathrm{CH} \mathrm{Im}\right), 7.23-7.51(\mathrm{~m}$, $6 \mathrm{H}, m$-aryl-H, $p$-aryl- $\mathrm{H}, 2 \mathrm{H}, \mathrm{CH}=\mathrm{CH} \mathrm{Im}, 5$-Pyr, 3-Pyr), $7.84(\mathrm{t}, J=$ $7.7 \mathrm{~Hz}, 1 \mathrm{H}, 4$-Pyr), 9.36 (d, $J=5.2 \mathrm{~Hz}, 1 \mathrm{H}, 6$-Pyr).

${ }^{13} \mathbf{C}\left\{{ }^{1} \mathbf{H}\right\}$ NMR $\left(\mathrm{CDCl}_{3}, T=298 \mathrm{~K}, \mathrm{ppm}\right), \delta: 23.6\left(\mathrm{CH}_{3}\right.$, iPr- $\left.\mathrm{CH}_{3}\right), 24.5\left(\mathrm{CH}_{3}\right.$, iPr- $\left.\mathrm{CH}_{3}\right), 24.8\left(\mathrm{CH}_{3}, \mathrm{iPr}-\mathrm{CH}_{3}\right), 25.8\left(\mathrm{CH}_{3}\right.$, iPr- $\left.\mathrm{CH}_{3}\right), 28.3\left(\mathrm{CH}\right.$, iPr-CH), $28.8\left(\mathrm{CH}_{3}, \mathrm{iPr}-\mathrm{CH}_{3}\right), 51.2\left(\mathrm{CH}_{3}\right.$, $\left.\mathrm{OCH}_{3}\right), 51.7\left(\mathrm{CH}_{3}, \mathrm{OCH}_{3}\right), 53.6\left(\mathrm{CH}_{3}, \mathrm{OCH}_{3}\right), 54.2\left(\mathrm{CH}_{3}, \mathrm{OCH}_{3}\right)$, $57.2\left(\mathrm{CH}_{2}, \mathrm{NCH}_{2}\right), 99.9(\mathrm{C}, \mathrm{C}=\mathrm{CI}), 120.8(\mathrm{CH}, \mathrm{CH}=\mathrm{CH} \mathrm{Im})$, 123.4 (CH, 3-Pyr), 123.9 (CH, m-Ph), 124.2 (CH, 5-Pyr), 124.9 (CH, $m-\mathrm{Ph}), 125.5(\mathrm{CH}, \mathrm{CH}=\mathrm{CH} \mathrm{Im}), 129.4(\mathrm{C}, \mathrm{C}=\mathrm{C}), 129.8$ (CH, p-Ph), 135.1 (C, i-Ph), 138.9 (CH, 4-Pyr), $145.3(\mathrm{C}, \mathrm{C}=\mathrm{C})$, 145.4 (C, o-Ph), 153.8 (C, 2-Pyr), 156.2 (CH, 6-Pyr), 159.2 (C, $\mathrm{C}=\mathrm{O}), 165.9(\mathrm{C}, \mathrm{C}=\mathrm{O}), 166.0(\mathrm{C}, \mathrm{C}=\mathrm{O}), 168.0(\mathrm{C}, \mathrm{C}=\mathrm{O}), 170.6$ $(\mathrm{C}, \mathrm{C}=\mathrm{O}), 171.5(\mathrm{C}, \mathrm{NCN})$.

IR (KBr pellets): $\nu_{\mathrm{C}=\mathrm{O}}: 1714 \mathrm{~cm}^{-1}, \nu_{\mathrm{C}-\mathrm{O}}: 1236 \mathrm{~cm}^{-1}$.

Elemental anal. (\%) for $\mathrm{C}_{33} \mathrm{H}_{37} \mathrm{I}_{2} \mathrm{~N}_{3} \mathrm{O}_{8} \mathrm{Pd}$ : C 41.12, $\mathrm{H} 3.87$, $\mathrm{N}$ 4.36. Found: C 41.25, H 3.99, N 4.27.

\section{Synthesis of complex 3d}

Reaction time: $10 \mathrm{~min}$. Temperature: $0{ }^{\circ} \mathrm{C}$. Yield 69\%. Color: orange.

${ }^{1} \mathbf{H}$ NMR $\left(\mathrm{CDCl}_{3}, T=298 \mathrm{~K}, \mathrm{ppm}\right), \delta: 2.53\left(\mathrm{~s}, 6 \mathrm{H}, \operatorname{aryl}-\mathrm{CH}_{3}\right)$, $3.56\left(\mathrm{bs}, 3 \mathrm{H}, \mathrm{OCH}_{3}\right), 3.70\left(\mathrm{~s}, 3 \mathrm{H}, \mathrm{OCH}_{3}\right), 3.84\left(\mathrm{~s}, 3 \mathrm{H}, \mathrm{OCH}_{3}\right)$, 3.89 (s, $\left.3 \mathrm{H}, \mathrm{OCH}_{3}\right), 3.94\left(\mathrm{~s}, 3 \mathrm{H}, \mathrm{NCH}_{3}\right), 5.51$ (bd, $1 \mathrm{H}, \mathrm{NCH}_{2}$ ), $5.90\left(\mathrm{~d}, J=15.2 \mathrm{~Hz}, 1 \mathrm{H}, \mathrm{NCH}_{2}\right), 6.89(\mathrm{~d}, J=1.8 \mathrm{~Hz}, 1 \mathrm{H}$, $\mathrm{CH}=\mathrm{CH} \mathrm{Im}), 7.12(\mathrm{~d}, J=7.4 \mathrm{~Hz}, 2 \mathrm{H}$, aryl $m-\mathrm{H}), 7.17-7.32(\mathrm{~m}$, $3 \mathrm{H}$, 5-Pyr, aryl $p-\mathrm{H}, \mathrm{CH}=\mathrm{CH} \mathrm{Im}), 7.73-7.85$ (m, 2H, 3-Pyr, 4-Pyr), 8.64 (d, $J=4.9 \mathrm{~Hz}, 1 \mathrm{H}, 6$-Pyr).

${ }^{13} \mathbf{C}\left\{{ }^{1} \mathbf{H}\right\}$ NMR $\left(\mathrm{CDCl}_{3}, T=298 \mathrm{~K}, \mathrm{ppm}\right), \delta: 19.0\left(\mathrm{CH}_{3}\right.$, $\left.\mathrm{Ar}-\mathrm{CH}_{3}\right), 39.5\left(\mathrm{CH}_{3}, \mathrm{NCH}_{3}\right), 52.1\left(\mathrm{CH}_{3}, \mathrm{OCH}_{3}\right), 52.3\left(\mathrm{CH}_{3}\right.$, $\left.\mathrm{OCH}_{3}\right), 52.9\left(\mathrm{CH}_{3}, \mathrm{OCH}_{3}\right), 53.7\left(\mathrm{CH}_{3}, \mathrm{OCH}_{3}\right), 55.6\left(\mathrm{CH}_{2}, \mathrm{NCH}_{2}\right)$, 122.5 (CH, 5-Pyr), $123.1 \quad(\mathrm{CH}, \quad \mathrm{CH}=\mathrm{CH} \quad \mathrm{Im}), \quad 124.3$ $(\mathrm{CH}, \mathrm{CH}=\mathrm{CH} \mathrm{Im}), 125.4$ (C, aryl i-C), 126.0 (CH, 3-Pyr), 128.3 (CH, aryl $m$-C), 130.4 (CH, aryl $p$-C), 136.5 (C, aryl $o$-C), 138.8 (CH, 4-Pyr), 151.6 (CH, 2-Pyr), 160.6 (C, $\mathrm{C}=\mathrm{O}), 163.8$ $(\mathrm{C}, \mathrm{NCN}) \cdot 166.6(\mathrm{C}, \mathrm{C}=\mathrm{O}), 172.8(\mathrm{C}, \mathrm{C}=\mathrm{O})$.

IR (KBr pellets): $\nu_{\mathrm{CN}}: 2190 \mathrm{~cm}^{-1}, \nu_{\mathrm{C}=\mathrm{O}}: 1714 \mathrm{~cm}^{-1}, \nu_{\mathrm{C}-\mathrm{O}}$ : $1230 \mathrm{~cm}^{-1}$

\section{Synthesis of complex $4 a$}

$0.0463 \mathrm{~g}$ (0.0566 mmol) of complex 3a was dissolved under an inert atmosphere (Ar) in ca. $15 \mathrm{ml}$ of anhydrous $\mathrm{CH}_{2} \mathrm{Cl}_{2}$ and stirred in the dark for 3 days at RT. The resulting solution was evaporated to a small volume under vacuum and finally the addition of diethyl ether induces the precipitation of the orange complex 4a which was filtered off on a gooch, repeatedly washed with diethyl ether and finally dried under vacuum. $0.0423 \mathrm{~g}$ (yield 92\%) of the complex $4 \mathrm{a}$ was obtained.

${ }^{1} \mathbf{H}$ NMR $\left(\mathrm{CDCl}_{3}, T=298 \mathrm{~K}, \mathrm{ppm}\right), \delta: 3.66\left(\mathrm{~s}, 3 \mathrm{H}, \mathrm{OCH}_{3}\right)$, $3.71\left(\mathrm{~s}, 3 \mathrm{H}, \mathrm{NCH}_{3}\right), 3.76\left(\mathrm{~s}, 3 \mathrm{H}, \mathrm{OCH}_{3}\right), 3.82\left(\mathrm{~s}, 3 \mathrm{H}, \mathrm{OCH}_{3}\right), 3.93$ $\left(\mathrm{s}, 3 \mathrm{H}, \mathrm{OCH}_{3}\right), 5.06$ (d, $\left.J=14.4 \mathrm{~Hz}, 1 \mathrm{H}, \mathrm{NCH}_{2}\right), 6.48$ (d, $J=14.4$ $\mathrm{Hz}, 1 \mathrm{H}, \mathrm{NCH}_{2}$ ), 6.76 (bs,1H, $\left.\mathrm{CH}=\mathrm{CH} \mathrm{Im}\right), 7.38$ (m, 1H, 5-Pyr), 
7.42 (bs, 1H, CH=CH Im), 7.59 (d, $J=7.7 \mathrm{~Hz}, 1 \mathrm{H}, 3-\mathrm{Pyr}), 7.83$ (t, $J=7.7,1 \mathrm{H}, 4-\mathrm{Pyr}), 8.84$ (d, $J=4.9 \mathrm{~Hz}, 1 \mathrm{H}, 6$-Pyr).

${ }^{13} \mathbf{C}\left\{{ }^{1} \mathbf{H}\right\}$ NMR $\left(\mathrm{CDCl}_{3}, T=298 \mathrm{~K}, \mathrm{ppm}\right), \delta: 36.9\left(\mathrm{CH}_{3}, \mathrm{NCH}_{3}\right)$, $51.8\left(\mathrm{CH}_{3}, \mathrm{OCH}_{3}\right), 52.4\left(\mathrm{CH}_{3}, \mathrm{OCH}_{3}\right), 53.3\left(\mathrm{CH}_{3}, \mathrm{OCH}_{3}\right), 54.1$ $\left(\mathrm{CH}_{3}, \mathrm{OCH}_{3}\right), 54.7\left(\mathrm{CH}_{2}, \mathrm{NCH}_{2}\right), 118.1(\mathrm{C}, \mathrm{C}=\mathrm{C}), 122.3(\mathrm{CH}$, $\mathrm{CH}=\mathrm{CH}$ Im), 125.9 (CH, 5-Pyr), $126.1(\mathrm{CH}, \mathrm{CH}=\mathrm{CH} \mathrm{Im}), 126.8$ (CH, 3-Pyr), 132.3 (C, C=C), 138.7 (CH, 4-Pyr), 139.8 (C, NCN), 151.7 (C, 2-Pyr), 154.8 (CH, 6-Pyr), 156.5 (C, C=C), 162.4 (C, $\mathrm{C}=\mathrm{C}), 162.7(\mathrm{C}, \mathrm{C}=\mathrm{O}), 165.4(\mathrm{C}, \mathrm{C}=\mathrm{O}), 165.9(\mathrm{C}, \mathrm{C}=\mathrm{O}), 171.6$ $(\mathrm{C}, \mathrm{C}=\mathrm{O})$.

IR (KBr pellets): $\nu_{\mathrm{C}=\mathrm{O}}: 1717 \mathrm{~cm}^{-1}, \nu_{\mathrm{C}-\mathrm{O}}: 1241 \mathrm{~cm}^{-1}$.

Elemental anal. (\%) for $\mathrm{C}_{22} \mathrm{H}_{23} \mathrm{I}_{2} \mathrm{~N}_{3} \mathrm{O}_{8} \mathrm{Pd}$ : C 32.32, $\mathrm{H} 2.84$, N 5.14. Found: C 32.36, H 2.77, N 5.04.

Complex $\mathbf{4 b}$ was obtained according to the above described protocols using the appropriate starting complex and $\mathrm{I}_{2}$. The yield, color, reaction time and, where necessary, some supplementary information will be reported below the title.

\section{Synthesis of complex $4 \mathrm{~b}$}

Reaction time: 28 days. Temperature: R.T. Yield 93\%. Color: orange.

${ }^{1} \mathbf{H}$ NMR $\left(\mathrm{CDCl}_{3}, T=298 \mathrm{~K}, \mathrm{ppm}\right), \delta: 2.04$ (s, 3H, o-mesityl$\mathrm{CH}_{3}$ ), 2.34 (s, 3H, o-mesityl- $\mathrm{CH}_{3}$ ), 2.39 (s, 3H, p-mesityl- $\mathrm{CH}_{3}$ ), $3.25\left(\mathrm{~s}, 3 \mathrm{H}, \mathrm{OCH}_{3}\right), 3.68\left(\mathrm{~s}, 3 \mathrm{H}, \mathrm{OCH}_{3}\right), 3.73\left(\mathrm{~s}, 3 \mathrm{H}, \mathrm{OCH}_{3}\right)$, $3.93\left(\mathrm{~s}, 3 \mathrm{H}, \mathrm{OCH}_{3}\right), 5.13\left(\mathrm{~d}, J=14.4 \mathrm{~Hz}, 1 \mathrm{H}, \mathrm{NCH}_{2}\right), 6.57$ (d, $J=$ $14.4 \mathrm{~Hz}, 1 \mathrm{H}, \mathrm{NCH}_{2}$ ), 6.92 (s, 1H, m-mesityl-H), 7.01 (s, 1H, $m$-mesityl-H), 7.23 (d, $J=2.1 \mathrm{~Hz}, 1 \mathrm{H}, \mathrm{CH}=\mathrm{CH} \mathrm{Im}), 7.39$ (d, $J=$ $2.1 \mathrm{~Hz}, 1 \mathrm{H}, \mathrm{CH}=\mathrm{CH} \mathrm{Im}), 7.45(\mathrm{ddd}, 1 \mathrm{H}, J=7.7,5.4,1.6 \mathrm{Im}$, 5-Pyr), 7.63 (d, $J=7.7 \mathrm{~Hz}, 1 \mathrm{H}, 3-\mathrm{Pyr}), 7.90$ (td, $J=7.7,1.6 \mathrm{~Hz}$, 1H, 4-Pyr), 8.97 (ddd, $J=5.4,1.6,0.7 \mathrm{~Hz}, 1 \mathrm{H}, 6$-Pyr).

${ }^{13} \mathbf{C}\left\{{ }^{1} \mathbf{H}\right\}$ NMR $\left(\mathrm{CDCl}_{3}, T=298 \mathrm{~K}, \mathrm{ppm}\right) \delta$ : $17.8\left(\mathrm{CH}_{3}\right.$, $o$-mesityl- $\left.\mathrm{CH}_{3}\right), 20.6\left(\mathrm{CH}_{3}, o\right.$-mesityl- $\left.\mathrm{CH}_{3}\right), 21.8\left(\mathrm{CH}_{3}, p\right.$-mesityl$\left.\mathrm{CH}_{3}\right), 51.2\left(\mathrm{CH}_{3}, \mathrm{OCH}_{3}\right), 51.2\left(\mathrm{CH}_{3}, \mathrm{OCH}_{3}\right), 52.9\left(\mathrm{CH}_{3}, \mathrm{OCH}_{3}\right)$, $53.5\left(\mathrm{CH}_{3}, \mathrm{OCH}_{3}\right), 56.3\left(\mathrm{CH}_{2}, \mathrm{NCH}_{2}\right), 116.2(\mathrm{C}, \mathrm{Pd}-\mathrm{C}-\mathrm{C}, \mathrm{C}=\mathrm{C})$, $123.6(\mathrm{CH}, \mathrm{CH}=\mathrm{CH} \mathrm{Im}), 125.7(\mathrm{CH}, 5-\mathrm{Pyr}), 125.9(\mathrm{CH}$, $\mathrm{CH}=\mathrm{CH} \mathrm{Im}$ ), 127.3 (CH, 3-Pyr), 129.2 (CH, m-mesityl), 130.1 (CH, m-mesityl), 130.7 (C, i-mesityl), 131.4 (C, Pd-C-I), 135.3 (C, o-mesityl), 137.0 (C, o-mesityl), 140.4 (C, p-mesityl), 138.9 (CH, 4-Pyr), 142.2 (C, NCN), 150.7 (C, 2-Pyr), 155.1 (CH, 6-Pyr), $159.8(\mathrm{C}, \mathrm{C}=\mathrm{O}), 161.4(\mathrm{C}, \mathrm{C}=\mathrm{C}), 164.6(\mathrm{C}, \mathrm{C}=\mathrm{O}), 165.3$ $(\mathrm{C}, \mathrm{C}=\mathrm{O}), 171.7(\mathrm{C}, \mathrm{C}=\mathrm{O}), 181.4(\mathrm{C}, \mathrm{C}=\mathrm{C})$.

IR (KBr pellets): $\nu_{\mathrm{C}=\mathrm{O}}: 1723 \mathrm{~cm}^{-1}, \nu_{\mathrm{C}-\mathrm{O}}: 1225 \mathrm{~cm}^{-1}$.

Elemental anal. (\%) for $\mathrm{C}_{30} \mathrm{H}_{31} \mathrm{I}_{2} \mathrm{~N}_{3} \mathrm{O}_{8} \mathrm{Pd}$ : C 39.09, $\mathrm{H}$ 3.39, $\mathrm{N}$ 4.56. Found: C 39.24, H 3.51, N 4.44.

\section{References}

1 (a) K. Mosely and P. M. Maitlis, J. Chem. Soc. D, 1971, 16041605; (b) T.-S. Ito, S. Hasegawa, Y. Takahashi and Y. Ishii, J. Organomet. Chem., 1974, 73, 401-409; (c) K. Mosely and P. M. Maitlis, J. Chem. Soc., Dalton Trans., 1974, 169-175; (d) D. M. Roe, C. Calvo, N. Krishnamachari and P. M. Maitlis, J. Chem. Soc., Dalton Trans., 1975, 125-132; (e) H. Suzuki, K. Itoh, Y. Ishii, K. Simon and J. A. Ibers, J. Am. Chem. Soc., 1976, 98, 8494-8500; $(f)$ H. tom Dieck,
C. Munz and C. Muller, J. Organomet. Chem., 1987, 326, C1-C5; ( $g$ ) C. Munz, C. Stephan and H. tom Dieck, J. Organomet. Chem., 1990, 384, 243-255; (h) C. Munz, C. Stephan and H. tom Dieck, J. Organomet. Chem., 1990, 395, C42-C45; (i) C. Munz, C. Stephan and H. tom Dieck, J. Organomet. Chem., 1991, 407, 413-420; $(j)$ R. V. Asselt, C. J. Elsevier, W. J. J. Smeets and A. L. Spek, Inorg. Chem., 1994, 33, 1521-1531; (k) J. Campora, P. Palma and E. Carmona, Coord. Chem. Rev., 1999, 193-195, 207-281.

2 (a) R. van Belzen, H. Hoffmann and C. J. Elsevier, Angew. Chem., Int. Ed. Engl., 1997, 36, 1743-1745; (b) R. Van Belzen, R. A. Klein, H. Kooijman, N. Veldman, A. L. Spek and C. J. Elsevier, Organometallics, 1998, 17, 1812-1825; (c) E. Shirakawa, H. Yoshida, Y. Nakao and T. Hiyama, J. Am. Chem. Soc., 1999, 121, 4290-4291; (d) H. Yoshida, E. Shirakawa, Y. Nakao, Y. Honda and T. Hiyama, Bull. Chem. Soc. Jpn., 2001, 74, 637-647; (e) L. Canovese, F. Visentin, G. Chessa, P. Uguagliati, C. Levi and A. Dolmella, Organometallics, 2005, 24, 5537-5548; (f) A. Holuigue, J. M. Ernsting, F. Visentin, L. Canovese and C. J. Elsevier, Organometallics, 2008, 27, 4050-4055.

3 (a) L. Canovese, F. Visentin and C. Santo, J. Organomet. Chem., 2014, 770, 6-13; (b) L. Canovese, F. Visentin, T. Scattolin, C. Santo and V. Bertolasi, Dalton Trans., 2015, 44, 15049-15058; (c) L. Canovese, F. Visentin, T. Scattolin, C. Santo and V. Bertolasi, J. Organomet. Chem., 2016, 808, 48-56; (d) L. Canovese, F. Visentin, T. Scattolin, C. Santo and V. Bertolasi, Polyhedron, 2016, 113, 25-34.

4 T. Scattolin, F. Visentin, C. Santo, V. Bertolasi and L. Canovese, Dalton Trans., 2016, 45, 11560-11567.

5 (a) M. W. Van Laren and C. J. Elsevier, Angew. Chem., Int. Ed., 1999, 38, 3715-3717; (b) K. Muñiz, Angew. Chem., Int. Ed., 2009, 48, 2-14; (c) L.-M. Xu, B.-J. Li, Z. Yang and Z.-J. Shi, Chem. Soc. Rev., 2010, 39, 712-733; (d) Y. Dang, S. Qu, J. W. Nelson, H. D. Pham, Z.-X. Wang and X. Wang, J. Am. Chem. Soc., 2015, 137, 2006-2014; (e) R. Van Belzen, C. J. Elsevier, A. Dedieu, N. Veldman and A. L. Spek, Organometallics, 2003, 22, 722-736; (f) A. R. Dick, J. W. Kampf and M. S. Sanford, J. Am. Chem. Soc., 2005, 127, 12790-12791; $(g)$ J. Vicente, A. Arcas, F. Juliá Hernández and D. Bautista, Angew. Chem., Int. Ed., 2011, 30, 6896-6899.

6 (a) J. Tsuji, in Palladium Reagents and Catalysts: Innovations in Organic Synthesis, Wiley and Sons, New York, 1995, ch. 4; (b) L. S. Hegedus, Coord. Chem. Rev., 1996, 147, 443-545; (c) L. S. Hegedus, Coord. Chem. Rev., 1997, 161, 129-255; (d) I. P. Beletskaya and A. V. Cheprakov, Chem. Rev., 2000, 100, 3009-3066; (e) C. Amatore and A. Jutand, Acc. Chem. Res., 2000, 33, 314-321; (f) R. Zimmer, C. U. Dinesh, E. Nandanan and F. A. Khan, Chem. Rev., 2000, 100, 30673125; (g) J. A. Marshall, Chem. Rev., 2000, 100, 3163-3186; (h) E.-I. Negishi, in Handbook of Organopalladium Chemistry for Organic Synthesis, ed. E.-I. Negishi and A. de Meijere, Wiley-Interscience, New York, ch. I.1, I.2, 2002; (i) K. Tamao, T. Hiyama and E.-I. Niegishi, 30 Years of the Cross-coupling Reaction, Special issue, J. Organomet. 
Chem., 2002, 653, 1-303. (j) L. A. Agrofoglio, I. Gillaizeau and Y. Saito, Chem. Rev., 2003, 103, 1875-1916; (k) E. Negishi and L. Anastasia, Chem. Rev., 2003, 103, 1979-2017; (l) G. Zeni and R. C. Larock, Chem. Rev., 2004, 104, 2285-2309; $(m)$ K. C. Nicolaou, P. G. Bulger and D. Sarlah, Angew. Chem., Int. Ed., 2005, 44, 4442-4489; (n) E.-I. Negishi, Bull. Chem. Soc. Jpn., 2007, 80, 233-257; (o) C. J. Elsevier and M. R. Eberhard, in Comprehensive Organometallic Chemistry III: From Fundamentals to Applications, ed. A. Canty, ed. in Chief R. H. Crabtree, D. Michael and P. Mingos, Elsevier, Amsterdam, Boston, 2007, ch. 8.05, vol. 8, pp. 270-298; ( $p$ ) M. García-Melchor, X. Solans-Monfort and G. Ujaque, in CC Bond Formation Comprehensive Inorganic Chemistry II: From Elements to Applications, ed. J. Reedijk and K. R. Poeppelmeier, Elsevier, Amsterdam, 2013, vol. 9, pp. 767-805.

7 L. Canovese, C. Santo, T. Scattolin, F. Visentin and V. Bertolasi, J. Organomet. Chem., 2015, 794, 288-300.

8 M. J. Frisch, G. W. Trucks, H. B. Schlegel, G. E. Scuseria, M. A. Robb, J. R. Cheeseman, G. Scalmani, V. Barone, B. Mennucci, G. A. Petersson, H. Nakatsuji, M. Caricato, X. Li, H. P. Hratchian, A. F. Izmaylov, J. Bloino, G. Zheng, J. L. Sonnenberg, M. Hada, M. Ehara, K. Toyota, R. Fukuda, J. Hasegawa, M. Ishida, T. Nakajima, Y. Honda, O. Kitao, H. Nakai, T. Vreven, J. A. Montgomery Jr., J. E. Peralta, F. Ogliaro, M. Bearpark, J. J. Heyd, E. Brothers, K. N. Kudin, V. N. Staroverov, R. Kobayashi, J. Normand, K. Raghavachari, A. Rendell, J. C. Burant, S. S. Iyengar, J. Tomasi, M. Cossi, N. Rega, J. M. Millam, M. Klene, J. E. Knox, J. B. Cross, V. Bakken, C. Adamo, J. Jaramillo, R. Gomperts, R. E. Stratmann, O. Yazyev, A. J. Austin, R. Cammi, C. Pomelli, J. W. Ochterski, R. L. Martin, K. Morokuma, V. G. Zakrzewski, G. A. Voth, P. Salvador, J. J. Dannenberg, S. Dapprich, A. D. Daniels, O. Farkas, J. B. Foresman, J. V. Ortiz, J. Cioslowski and D. J. Fox, Gaussian 09', Gaussian, Inc., Wallingford, CT, 2009.

9 L. Schrodinger, The PyMOL Molecular Graphics System, Schrodinger, LLC, 2015.

10 A. A. Danopoulos, N. Tsoureas, J. C. Green and M. B. Hursthouse, Chem. Commun., 2003, 756-757.

11 K. J. Cavell and D. S. McGuiness, Coord. Chem. Rev., 2004, 248, 671-681 and refs. therein.

12 A. Spek, Acta Crystallogr., Sect. D: Biol. Crystallogr., 2009, 65(2), 148-155.
13 No TS has been found in the case of the rearrangement of intermediate $\mathbf{I}^{\prime}$ to $\mathbf{4 a}^{*}$. On the contrary a possible TS for the 4a-4a* process was identified at $\Delta G=-0.7 \mathrm{kcal} \mathrm{mol}^{-1}$. It might be therefore plausible that complex $4 \mathbf{a}^{*}$, instead of an intermediate species eventually yielding the complex $\mathbf{4 a}$, would represent a thermodynamically disfavored final target or an unproductive alternative path of the rearrangement sequence.

14 Y. Zhao and D. G. Truhlar, Acc. Chem. Res., 2008, 41, 157167.

15 Y. Zhao and D. G. Truhlar, Theor. Chem. Acc., 2008, 120, 215-241.

16 (a) P. J. Hay and W. R. Wadt, J. Chem. Phys., 1985, 82, 270283; (b) P. J. Hay and W. R. Wadt, J. Chem. Phys., 1985, 82, 299-310.

17 L. E. Roy, P. J. Hay and R. L. Martin, J. Chem. Theory Comput., 2008, 4, 1029-1031.

18 C. E. Check, T. O. Faust, J. M. Bailey, B. J. Wright, T. M. Gilbert and L. S. Sunderlin, J. Phys. Chem. A, 2001, 105, 8111-8116.

19 V. Barone, M. Cossi and J. Tomasi, J. Chem. Phys., 1997, 107, 3210-3221.

20 V. Barone and M. Cossi, J. Phys. Chem. A, 1998, 102, 19952001.

21 (a) C. J. Cramer, Essentials of Computational Chemistry, Wiley, Chichester, 2nd edn, 2004; (b) F. Jensen, Introduction to Computational Chemistry, Wiley, Chichester, 2nd edn, 2007.

22 A. Lausi, M. Polentarutti, S. Onesti, J. R. Plaisier, E. Busetto, G. Bais, L. Barba, A. Cassetta, G. Campi, D. Lamba, A. Pifferi, S. C. Mande, D. D. Sarma, S. M. Sharma and G. Paolucci, Eur. Phys. J. Plus, 2015, 130, 1-8.

23 W. Kabsch, XDS, Acta Crystallogr., Sect. D: Biol. Crystallogr., 2010, 66, 125-132.

24 G. M. Sheldrick, $S A D A B S$, University of Göttingen, Germany, 2012.

25 G. M. Sheldrick, SHELXT, Acta Crystallogr., Sect. A: Fundam. Crystallogr., 2015, 71, 3-8.

26 G. M. Sheldrick, SHELXL, Acta Crystallogr., Sect. C: Cryst. Struct. Commun., 2016, 71, 3-8.

27 P. Emsley and K. Cowtan, Acta Crystallogr., Sect. D: Biol. Crystallogr., 2004, 60(12), 2126-2132http://www.pymol.org.

28 L. Farrugia, J. Appl. Crystallogr., 2012, 45(4), 849-854. 